\title{
Degeneration \\ - Den sunde krop som symbol
}

\section{Af Hans Bonde}

Som i første halvdel af det tyvende århundrede står vi i dag over for trusler om menneskekroppens forfald. Kan vi tage ved lære af den farlige politiske og religiøse sundhedsfanatisme, der udviklede sig i angsten for degeneration efter år 1900? Hvordan undgår vi, at nutidens markante sundhedsproblemer afstedkommer et hysteri, der kun gør ondt værre?

Denne forelæsning skal afbalancere flere hensyn. For det første skal den som tiltrædelsesforelæsning være forskningsbaseret og for det andet gerne præsentere væsentlige dele af min egen forskning herunder om end sporadisk berøre min interesse for idræt i relation til maskulinitet, politik og national identitet. For det tredje skal den være formidlende over for en større offentlighed, fordi den indgår i en foredragsrække om Sundhed og Idræt på Institut for Idræt i København. Jeg vil derfor lade den munde ud i konkrete forslag til alternativ sundhedstænkning. Den må for det fjerde gerne lægge op til en tværvidenskabelig dialog, da de tre næste foredrag i rækken er naturvidenskabeligt orienterede. ${ }^{1}$

\section{Forfaldstanker}

»Stcerkere og starkere lyder råbene om, at menneskeslagtens sundhed går tilbage, at den opvoxende slagt stedse viser sig at stå tilbage for forfadrene, at b $\phi r$ - nene ikke meer kunne tåle de samme legemlige eller åndelige anstrangelser som den tidligere slagt, at nervøsiteten breder sig og formelig giver århundredet sit proeg, så at der tales om »nervøsitetens århundrede«, at stedse flere unge mand kasseres ved sessionerne, og således $i$ det uendelige ${ }^{2}{ }^{2}$

Dette skrækscenarium er ikke fremkommet i dag, men for over 100 år siden, da kommunelæge Michael Larsen i 1889 ville advare mod menneskeslægtens deroute. Angsten for degeneration var et tidens tegn i slutningen af 1800 -tallet ${ }^{3}$, ikke mindst på grund af de velhavende klassers grovæderi, mellemlagenes nervesygdomme og underklassens fattigdom og sammenklumpning i byernes lejekaserner uden adgang til lys, luft og renlighed. Det var en udbredt forestilling, at erhvervede egenskaber kunne nedarves, hvorfor de degenererede arveanlæg ville gå i arv fra generation til generation. Men også dårlige sociale og miljømæssige forhold kunne medvirke til degenerationen i samme slægtled. I min Ph.d.-afhandling Mandighed og sport fra 1991 behandlede jeg degenerationsangsten blandt sportspionerer, der frygtede, at den moderne mand ville blive overciviliseret og mindre maskulin via udbredelsen af det stillesiddende arbejde. I en fra engelsk oversat idrætstekst fra 1886 hed det om befolkningen i London, at 
»den tredje generation af denne klasse mennesker vil vise sig at vare svagelig, og bornene af denne generation ville kun sjoeldent nå den modne alder... 'Fremtidens mand' vil ikke alene blive tandløs og skaldet og ude af stand til at bevage sig frit omkring på sine dårlige fødder, men han vil også vare sardeles utilbøjelig til at indlade sig $i$ personlig kamp - han vil blive en tilbeder af fred for enhver pris«. ${ }^{4}$

Skønt lægevidenskaben omkring år 1900 gik mere og mere bort fra degenerationsteorien som arvelære og omkring 1914 helt forlod den, spillede den, som historikeren Lene Koch har vist, fortsat en vigtig rolle i den offentlige debat, ikke mindst i mellemkrigstidens debat om racehygiejne. ${ }^{5}$

Degenerationsteorien var tæt sammenknyttet med den udbredte opfattelse af samfundet som en organisme, en krop, der, hvis ikke den blev udsat for forebyggelse, pleje og behandling, ville rammes af sygdom. Hvad, der skulle ske med det syge eller døde sociale væv, afhang af, om man socialhygiejnisk ville forbedre livsvilkårene for de hårdest ramte eller som i den såkaldt negative racehygiejne ville forhindre de mindst egnede $\mathrm{i}$ at formere sig. Samfundet som organisme viste sig ifølge etnologen Karin Lützen f.eks. hos psykiateren Knud Pontoppidan, der i 1886 skrev, at $\gg$ vor hovedstad er netop nu nået op til at blive en stor by, hvor den komplicerede og potenserede tilværelse er udtryk for et overinciteret nervesystem $\ll{ }^{6}{ }^{6}$

Som en parallel til de degenerative $»$ nervesygdomme« omkring år 1900, står vi i dag over for omfattende problemer med stress i en tid, der stiller stadig større krav til omstillingsevne og effektivitet. Lægen Abraham Clod-Hansen beskrev i sin bog Mand og kvinde fra 1895 en problematik, der virker overraskende nutidig; den »maladie du siècle«, som kaldtes generel parese: »En overanstrengelsessygdom, der viser, at et individ trods sine anstrengelser er kommet til kort, idet det under livets konkurrence har løbet sig mat «. ${ }^{7}$ Denne sygdom ramte især den opstræbende middelklasses mænd og var ifølge Clod-Hansen en konsekvens af mændenes voksende deltagelse i livets storm langt væk fra hjemmets trygge arne. Ret profetisk gjorde han opmærksom på, at også kvinderne, i den udstrækning de begyndte at deltage i det frembrydende borgerlige samfunds udearbejde, måtte se frem til at betale den samme pris.

Omkring år 1900 blev idrætten set som et middel, der kunne skabe regeneration frem for degeneration, altså modvirke nervesvækkelsen og vitalisere ikke mindst den mandlige ungdom som modvægt mod det dræn af ressourcer, der mentes at foregå gennem onani, såkaldt kontrær seksualitet (homoseksualitet) og i det hele taget den feminisering, der mentes at true den overciviliserede borgermand med libertinske lader, pyntesyge og forfængelighed i kropsudtryk og adfærd. I Frankrig blev satsningen på national regeneration gennem koblingen af idræt og soldateruddannelse inspireret af ønsket om revanche efter nederlaget $\mathrm{i}$ den fransk-tyske krig i 1870-71 - det var faktisk De Olympiske Leges grundlægger Pierre de Coubertins oprindelige motivation for at interessere sig for sport - i Storbritannien af truslerne mod imperiets grænser herunder vanskelighederne med at afslutte boerkrigen i 1899-1902 - en krig der i øvrigt inspirerede Baden Powell til at skabe spejderbevægelsen $^{8}$ - og i Danmark af ønsket om at vinde Sønderjylland tilbage. Der var altså klare forbindelser mellem krig og sport.

Degenerationsteorien var inspireret af 


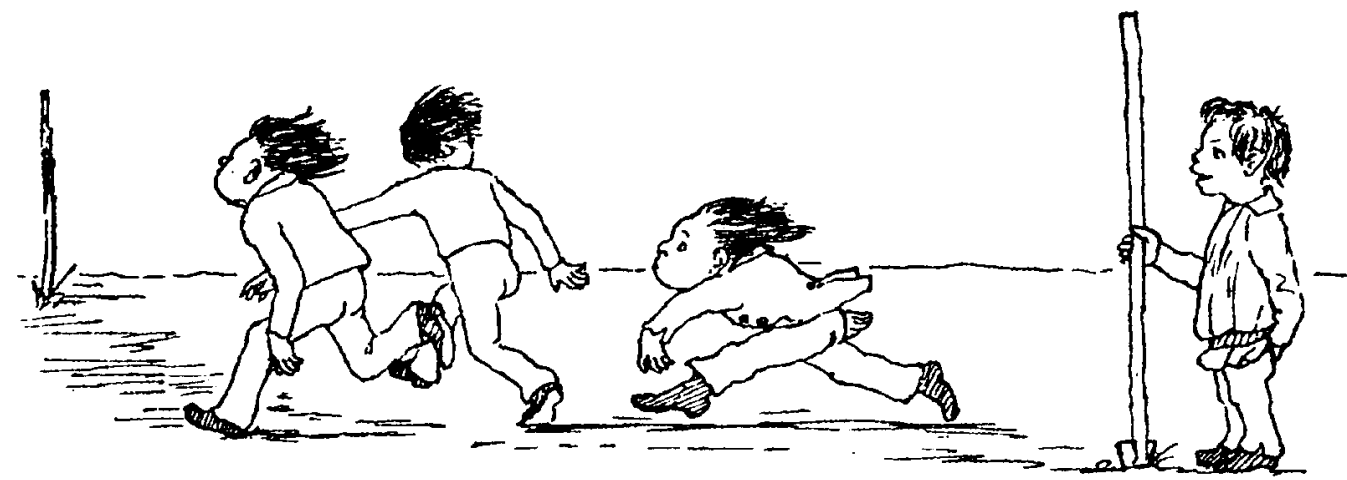

"Drengene i skolen lфber om kap. Gysse bliver stående til de kommer tilbage, overvejende at han således vil komme lige så vidt som de andre med ringere uleglighed. Tegning af Fritz Jürgensen fra 1840'erne.

socialdarwinismens forestilling om »survival of the fittest «, og med forbindelsen til idrættens regeneration fik »fit« en meget konkret fysisk drejning, jvf. det moderne kropskulturelle begreb »fitness «.

I 1892 udgav forfatteren Max Nordau bestselleren Entartung, der blev oversat til engelsk i 1895 med titlen Degeneration. Heri beskrev han tidstypisk, hvordan den nye tendens til storbyer skabte grobund for nervelidelser. Om vores tid profeterede han:

»I slutningen af det tyvende århundrede vil man formentlig blive vidne til en generation, for hvem det ikke vil vare sundhedsfarligt at lose masser af aviser hver dag, hele tiden at blive afbrudt af telefonen [hvad ville Nordau mon have sagt til mobiltelefonen?], konstant at have alle fem kontinenter i tankerne, det halve liv at vare på farten i flyvemaskiner og tog ... Den vil kunne finde ro selv midt $i$ en millionby ${ }^{9}{ }^{9}$

Og ganske rigtigt: Vores sanseapparat har i dag i en vis udstrækning vænnet sig til den moderne urbane hastighedskultur, skønt den, som den franske filosof, arkitekt og byplanlægger Paul Virillio har beskrevet det i sin teori om »dromologi $\ll$ (dromos: græsk: $1 \varnothing b)$, endog er for $\varnothing$ get enormt siden år 1900. ${ }^{10}$ Men hvor det på dette tidspunkt især var den maskinelle transportkultur, der banede sig vej i form af biler, sporvogne, tog og storbyernes anonyme, defilerende menneskemasser, der pirrede sanserne, er det i dag tanketransporten i form af TVapparaterne og computernes virtuelle rum, der medfører degeneration af den fysiologiske krop. Hvor man tidligere kunne blive syg af at bevæge sig ud i metropolens hektiske puls, tager man i dag skade af at trække sig væk fra byen med dens krav om bevægelse og personlig kommunikation og ind i sig selv og sin egen teknologibefordrede fantasiverden.

\section{Drøm og realitet}

Kommunelæge Michael Larsens advarsel fra 1889 kunne derfor lige så godt være fremkommet i dag, hvor forsvarschefen efter sidste session kunne konstatere, at $42 \%$ af de unge danske mænd måtte kasseres, 
f.eks. fordi de var for dumme, for fede eller havde fysiske skader, såsom svage ben, dårlig ryg eller musearme. I 1800-tallets anden halvdel blev kandidaterne afvist på session, fordi de var for små, nu kasseres de, fordi de er for store. Det skal dog understreges, at en del af nutidens frafald nok skyldes bevidste fors $\varnothing \mathrm{g}$ på at unddrage sig værnepligt.

Hvis vi trækker på mine fysiologiske kollegers arbejder, kan frafaldet ved sessionerne ikke undre, eftersom der fra 1984-98 blandt de 15-årige kan konstateres et fald i antallet af unge aktive idrætsudøvere blandt dem, der træner mindst fire timer om ugen. For drengenes vedkommende fra $75 \%$ til $50 \%$ og hos pigerne fra $63 \%$ til $31 \%$. Og 30 $\%$ af de 16-18-årige dyrker fortsat slet ikke sport i deres fritid. De inaktive er mere hjælpeløse, ensomme og har dårligere selvtillid. Fremtidens motionssvage unge vil stå endnu dårligere, eftersom der er sket et fald $\mathrm{i}$ konditionstallet på $20 \%$ på 12 år fra 19851997 hos de mest utrænede 9-årige drenge. ${ }^{11}$

I USA er mere end hver fjerde person i dag svært overvægtig, hvilket også gælder omkring $17 \%$ af EU-borgerne, og i Danmark er der sket en fordobling siden midten af 1980'erne. 20-30\% af befolkningen er nu så fysisk passive, at folkesundheden er truet. Spørgsmålet er, om ikke den fedmeepidemi, vi har set i USA, nu for alvor er ved at brede sig til Danmark.

Det 20. århundredes vesteuropæiske samfund har fremvist store resultater inden for ernæringsvidenskab, hygiejne og sygdomsbekæmpelse. Maskinerne syntes endegyldigt at befri menneskenes kroppe fra årtusinders hårde og deformerende arbejde. På kontorerne er man nu blevet fri for at skulle gå ud på gangen med risiko for at møde sine kolleger, for mange kontorer er blevet udstyret med egen printer og egen kaffemaskine. Man er nu sluppet for selv at skubbe døre op og for med egen kraft at gå op ad trapper (hvem har i øvrigt fundet på, at man skal stå på en rulletrappe?). De små poder bliver ikke længere udsat for at $m \varnothing$ de børnelokkere, for legegaderne, hvor drengene spillede klink, bold eller drev top, er for længst blevet erobret af bilerne, og beskyttede legerum under behørigt opsyn er blevet indrettet i børnehaverne. Børnene bliver nu kørt sikkert til skole hver dag, så de ikke risikerer at blive kørt over af de andre børns forældre, der også vil bringe deres børn sikkert til skole. Rulleskøjten er blevet fortrængt af rulletrappen. Samtidig med at de handikappedes liv normaliseres, handikappes de raske.

$\mathrm{Vi}$ troede, at vi skabte verdens bedste samfund, hvor vores forfader i form af den skævvredne, stive, krumme og sultne bonde blev afløst af nutidens sunde, afslappede og dynamiske velfærdsborger. Men i kølvandet på velfærden udbredtes passivitetens tyranni. Vi drømmer fortsat om at blive opvartet, mens vi ligger som Jeppe i baronens seng. Mentalt er vi stadig bønder. Men vore kroppe lever i det 21 . århundrede, kroppe hvis genetiske udrustning er formet til et aktivt liv gennem de tusinder af år, hvor vi levede som jægere og samlere med stærke daglige krav til fysisk aktivitet.

Det er et fremskridtets paradoks, at det enorme samfundsmæssige overskud i Vesten bliver misforvaltet. Overfloden fører til fast- og junkfood, afskaffelsen af de nedslidende arbejdsbevægelser fører til motorisk stilstand, og sportselitens stadigt mere ekvilibristiske udfoldelser følges af massernes passive sportskonsum. Hvor både børn og voksne i tidligere samfund ofte legede med kroppen som indsats, er det store problem i dag, at man kan lege uden at røre sig. Mens ens egen virtuelle krop hvirvler rundt på skærmen, sidder den fysiske krop stille og kigger på. Det legende 
menneske - homo ludens - er blevet til det stillesiddende menneske, homo sedans.

Hvor den fede krop tidligere var et symbol på velnærethed, pondus og rigdom, har nutidens overklasse for længst læst skriften på vægten og viser karakterstyrke og social distance gennem at dyrke motion og spise sundt. Med Cristopher Lasch' præcise diagnose $^{12}$ fors $\emptyset$ ger den samfundsmæssige elite gennem kropstræning og -indgreb i videst muligt omfang at opnå vægtløshed gennem at frigøre sig fra kroppens afhængighed af tidens og rummets tyngde. Underklassens mennesker, der tidligere arbejdede sig en pukkel til, har i mellemtiden flyttet puklen fra ryggen til maveregionen. Og mens vi i vesten i stadig højere grad dør af passivitetsrelaterede sygdomme som hjerte-karlidelser, dør indbyggerne i U-landene fortsat af sult. Vi svulmer op, mens de skrumper ind. I sandhed en global uligevægt. Men det globale gennemsnitlige BMI (Body Mass Index) stemmer.

Men kan vi ikke bare lære at spise lidt mindre og lidt grønnere for at blive sunde? $\mathrm{Nej}$, for den fysiologiske forskning er blevet bedre og bedre i stand til at beskrive de negative effekter af manglen på bevægelse. Idrætsforskeren Lars Bo Andersen har peget på, at bevægelse ikke kun medfører en forøget kalorieforbrænding, men frem for alt en bedret stofskiftefunktion og appetitregulering.

Den internationalt kendte muskelfysiolog Bengt Saltin har rammende sagt, at det er bedre at have en velpolstret og veltrænet krop end en slank og utrænet. Herved har han rammet en pæl gennem den udbredte myte, at man kan blive sund alene ved at spise sundt. Det bedste kostråd er motion! Vi ved nu, at en lang række sygdomme kan mildnes eller direkte helbredes ved at bevæge sig.

Risikoen for at $\mathrm{d} \varnothing$ af fysisk passivitet er på niveau med faren ved at ryge. Inaktiviteten er imidlertid en langt større trussel, fordi der er langt flere motionssvage, end der er rygere. Ikke desto mindre er motion et ret nyt middel i forebyggelsessammenhæng i modsætning til rygebekæmpelsen. Der er derfor endnu kun en svag tradition for at opbygge netværk og starte initiativer på dette område.

Det er et paradoks, at de fleste mennesker kan forstå, at en bil ruster, når den ikke bruges og vedligeholdes, men den samme erkendelse er ikke nær så udbredt, når det gælder menneskekroppen, der via inaktivitet tæres gennem slidgigt, knogleskørhed og rygproblemer. Kaptajn Jespersens gamle kobling af »ratslaver $\ll$ og »bilmaver« står stadig ved magt.

\section{Humanistisk sundhedsforskning}

Hvor den naturvidenskabelige forskning i dag kan påvise de negative medicinske virkninger af inaktivitet, kan den humanistiske sundhedsforskning fremdrage eksempler på, hvordan kampen mod degeneration i tidligere perioder har ført til et religiøst og politisk hysteri om menneskeslægtens nærtstående undergang, der kan give advarsler til nutidige sundhedsstrategier. Den humanistiske analyse ser »degenerationen « som et kulturelt symbolsystem, et skræmmebillede om menneskehedens forfald om end begrundet i reelle sundhedsmæssige trusler. Også i nutiden dukker der af og til stærke skræmmebilleder op. F.eks. da den amerikanske professor James O. Hill på en nylig fedmekonference i København sagde, at »fortsætter udviklingen som hidtil i USA, vil ni ud af ti amerikanere i løbet af de næste ti-tyve år være overvægtige«. Problemet er, at hvis 
forskerne virkelig fors øger at råbe politikerne op, risikerer de samtidig at bære ved til sundhedshysteriets bål.

Danmark har fostret to internationalt kendte idrætspædagoger, der har promoveret den sunde krop. Søger man i udenrigsministeriets arkiver, vil man kunne konstatere, at I.P. Müller - som jeg i øjeblikket skriver på en bog om - og Niels Bukh er de to eneste idrætspædagoger, der figurerer i større omfang, ganske enkelt fordi deres popularitet ude i verden var så stor, at de fik betydning for Danmarks anseelse i udlandet og dermed i yderste konsekvens for salget af Danish Bacon. (Det er altså griseproduktionen, der tænkes på).

I.P. Müllers (1866-1938) bog om hjemmegymnastik fra 1904 Mit System blev oversat til 26 sprog og solgt i 1 1/2 million eksemplarer. ${ }^{13}$ I Tyskland anvendtes der ligefrem et begreb »zu müllern « om dyrkelsen af hans frotteringsøvelser. Müller blev en med et moderne udtryk holistisk sundhedsforkæmper i en tid, hvor den medicinske verden ellers mere og mere forlod ideen om en bred sundhedslære til fordel for en fiksering på mikrober, vitaminer og biokemiske detaljer. Müller skrev i sin karakteristiske stil, at den, som ikke afrensede bakterierne fra legemet, risikerede, at mikroberne vandrede ind gennem huden, hvilket uvægerligt ville resultere $\mathrm{i} \gg d$ det hygiejniske krak«.

I.P. Müller fik stor betydning for degenerationsteoriens udbredelse i Danmark. I Mit System tegnede Müller billedet af den degenererede danske antihelt på sin malende facon:

$» B y$-kontorist-typen er ofte en sørgelig fremtoning. I den unge alder allerede duknakket, skavvskuldret og skavhoftet af den forvredne kontorstolsstilling, bleg, filipenseret og pomadiseret, med den tynde hals stikkende frem af en flip, som en normal mand kunne bruge som manchet, den lapsede påkladning efter nyeste mode, med armer og bukser slaskende om tynde pibestilke.$^{14}$

Müller intonerede den moderne fedtfobi ved at udmale fedtets afskyelighed:

»En muskel $i$ hvile udviser altid en harmonisk form, medens fedt aflejrer sig $i$ usymmetriske stygge, klumper ${ }^{15}{ }^{15}$

Müllers tilslutning til den frembrydende racehygiejne medførte en kamp mod alt det, der ifølge ham hindrede slægtens perfektion. I bogen »Kønsmoral og livslykke« fra 1908 foreslog han, at der blev ansat sygdomskonsulenter eller »hygiejneinspektører « i de danske sogne, der fik ret til at nedlægge forbud mod »bevislig skadelig børneavling «, f.eks. af »drankere, epileptikere og syfilitikere«. Hans overvejelser mundede ud i en kritik af den moralske degeneration og rummede en vision om et samfund, hvor alle »dårlige elementer « var renset væk. Sandheden var, at der var »overbefolkning « af en slags mennesker og »folkemangel « på en anden slags. Allerede nu er der nemlig alt for mange »sygelige, usunde, sindssvage, forbryderiske, onde, dovne og unyttige mennesker «. ${ }^{16}$

Gennem lægevidenskab, racehygiejne og personlig hygiejne skulle menneskeheden løftes ud af sygdommens sorte skygger og ind i en ophøjet, lys og ren verden. Müllers tekster var præget af et religiøst billedsprog. Hans visioner om, at menneskeslægten kunne fuldkommengøres, mennesker blive 160 år gamle og leve et sygdomsfrit liv, havde klare religiøse overtoner. Det var derfor ikke noget tilfælde, at I.P. Müller overalt blev kaldt sundhedsapostelen. Han fik på sine gamle dage en di- 
rekte religiøs vækkelse, idet han mente fra Gud at have modtaget evner til via »himmelsk fluidum « at helbrede sygdomme, som lægerne for længst havde opgivet. Egentlig skægt, at han blev grinet ud af det københavnske borgerskab, når han $\mathrm{i}$ dag blot kunne have nedsat sig som healer.

Müllers kobling af vækkelse og racehygiejne var en farlig cocktail, som i en yderligere perverteret og racistisk form udvikledes i nazismen, hvor den veltrænede ariske ungdom skulle danne grundstammen i den sunde samfundsorganisme. Dyrkelsen af sol, vegetarianisme, sunde beklædningsvaner, nøgenhed, friluftsliv, fri seksualitet, og sund levevis blev i 1920'ernes tyske livsreformbevægelse efterhånden alliancepartner for den gryende racehygiejne.

Müllers efterfølger og radiogymnastikkens faderskikkelse fra 1927-1952, Kaptajn Jespersen, ${ }^{17}$ følte, at han havde et kald, når han sagde: »Det onde skal drives ud af kroppen«. Hvad gav Kaptajn Jespersen en så stor gennemslagskraft, at han blev en myte i sin egen tid? Kaptajn Jespersen følte, at han i forbindelse med sin egen angiveligt mirakuløse helbredelseshistorie - der dog ikke kunne forhindre ham $i$ at forblive halt resten af livet - var blevet kaldt af Gud til, som vækkelsesprædikant, gennem kroppen at vække danskerne fra deres åndelige dårskab. Han accepterede, at lytterne stod kolde under de lange indslag med åndelige formaninger mellem hans $\emptyset$ velser, for det vigtigste var hans spirituelle budskab: Når Kaptajn Jespersen kæmpede mod alt det »formløse, uskønne og urene « og priste den »jernhånd «, der kunne styre den syndige krop, ses det, hvor tæt han var på pietismens kaldsetik og mere generelt på hele den dualistisk lutherske opfattelse af menneskets spaltning i en ophøjet ånd og en lav, frivol og dyrisk kødelighed.

Kaptajn Jespersens sprogbrug var stærkt præget af til situationen omformede Paulus-citater. Kroppen var potentielt et Guds tempel. Den krumme, fede, skæve og i det hele taget degenererede krop var derimod den syndige krop. Kroppen afslørede ubønhørligt, om man var syndig eller ren: »Den store hær af deformerede og halvt udviklede mennesker, vi har i dette land ... kan vi jo ligefrem udpege blandt folk ved deres skikkelse«. Som kronen på sit livsværk endte Kaptajn Jespersen med at holde foredrag i de danske kirker om den rette og rene levemåde. Kirken drog kort sagt nytte af hans evne til vækkende appel.

Hvor I.P. Müllers sundhedsutopier blev mere og mere gennemsyret af religiøs fanatisme, blev Niels Bukh (1880-1950) i stigende grad præget af politisk utopisme. ${ }^{18}$ Skønt hans gymnastik langt fra kan siges at være sund, og slet ikke for ryggen, blev den for ham et symbol på den sunde, ranke og dynamiske ungdom, der skulle skabe et nyt samfund med inspiration fra Det Tredje Rige. Niels Bukhs succes i den danske landbefolkning beroede på, at han fandt en kur mod den »degeneration « af de danske karle, der viste sig i den krummede mandekrop med dens stive og ufri bevægelser. Kuren hed "primitiv gymnastik «, der i bogstaveligste forstand medvirkede til, at den underlegne bonde kunne ranke sig i forhold til medlemmer af de »højere« samfundsklasser. I den tyske propagandaorganisation Nordische Gesellschafts blad skrev Bukh i 1939: »Et stift, kraftesløst og kejtet menneske er både uskønt og udygtigt til alt ... Med færrest mulige ord kan mit gymnastiske arbejdes virkning og mål udtrykkes således:

»Den primitive gymnastik fremarbejder den ideelle ungdomstype! Idratsgymnastikken åbenbarer den ideelle ungdomstypes skønhed og vardi!!. 
Som jeg viste i min disputats om $»$ Danmarks store ungdomsfører «, var Niels Bukhs vision intet mindre end at gøre Danmark til et verdenscentrum for kropskultur. Derfor byggede han så stort på sin gymnastikhøjskole i Ollerup, at selv hans arkitekt måtte korse sig. Om Niels Bukh ved vi, at han umiddelbart efter den nazistiske magtovertagelse i 1933 var optændt af nazismen $i$ en grad, der nærmede sig en uforbeholden Førerdyrkelse. At han i den anledning opmuntrede den danske ungdom til at gribe ind. At han gennem 1930'erne fortsat nærede en dyb beundring for Hitler og det nazistiske Tyskland og samarbejdede med nazistiske idrætsautoriteter og propagandaorganisationer. At han håbede på skabelsen af en europæisk blok på baggrund af en tysk sejr helt frem til foråret 1943. At han skabte planer til ungdomsforbund og arbejdstjeneste, der - ikke mindst i lyset af hans pro-tyske holdninger - kunne være blevet en fare for dansk demokrati. At han uden den danske regerings vidende forhandlede om en dansk arbejdstjeneste med den tyske rigsarbejdstjenestes ledere i april 1942. Og at han planlagde en »fredsfest « efter den forventede tyske sejr. Med et sejrrigt Tyskland i ryggen tyder alt på, at tyskernes lille ariske kultsted mod Nord ville få en væsentlig rolle i en nyorganiseret europæisk ungdomskultur.

Både Bukh og Müller var i pagt med »vitalismen«, den kulturopfattelse og kunstretning, der var udbredt i Danmark fra omkring år 1900 til 1920, og som hos en maler som J.F. Willumsen medførte en hyldest til livets lyse, ungdommelige og aktive aspekter. Hos en forfatter som Johannes V. Jensen ytrede vitalismen sig i en stærkt handlingspræget prosa, en amerikansk inspireret hyldest til udendørslivet og i en filosofi, der er koncentreret i den herostratisk berømte sætning om $\gg$ de raskes ret til riget $\ll .{ }^{19}$

\section{Moderne sundhedsfanatisme}

Hvorfor ledsages sundhedsdyrkelsen i særlig grad af politisk og religiøs fanatisme? Fordi menneskets drøm om at undgå sygdom og (tidlig) død er lige så lang som menneskeheden selv. Hvor religionen tidligere fors $\emptyset$ gte at give meningsfulde svar på livets udsathed, bliver sundhedsdyrkelsen i moderne tid stedet, hvor mennesker søger mod dennesidig frelse. Den sundhedsguru eller det politiske system, der postulerer at kunne dæmme op for degenerationen og garantere sunde samfundsborgere med sunde kroppe, vil ofte kunne mønstre fanatisk opbakning.

Hvor »racehygiejnen « i mellemkrigstiden var en utopi på kollektivt plan, er den $\mathrm{i}$ dag blevet individualiseret til forholdet mellem lægen og det kommende forældrepar, der kan afgøre, om fostret er uønsket eller ej ud fra dets genetiske profil. Endelig er der igen ved at opstå politiske sundhedsutopier, der forkynder menneskets endelige forløsning fra sygdom og tidlig $\mathrm{d} \varnothing \mathrm{d}$ gennem de såkaldte transhumanisters drømme om usårlighed og udødelighed i deres sammensmeltning med teknologien.

Der er væsentlige forskelle i forestillingerne om degeneration i mellemkrigstiden og i dag, f.eks. i forskydningen i interessen fra det psykiske til det fysiske forfald. Men ligesom man dengang ledte efter fysiske »stigmata « på samfundets såkaldte undermåleres degeneration, er det også i dag stærkt stigmatiserende at tilhøre gruppen af fede »overmålere«, der lever med risiko for social udstødning, mobning og dårligere salgbarhed på arbejdsmarkedet. Og dengang som nu bliver de negative tegn på kroppen tolket som udtryk for moralsk anløbenhed. Den fede krop ses som udtryk for manglende selvkontrol over for bordets glæder og alle andre fristelser. 
Spørgsmålet er, om der i dag er ved at opstå en ny individuel renselseskult, der tilbeder den asketiske og atletiske, slanke krop, der foreskriver faste før badesæsonen og gymnastiske bodsøvelser, der kræver renselse af den truede krop gennem daglige bade og kure og minutiøs koncentration omkring fødeindtagets kvalitet og kvantitet, og som finder sine åndelige vejledere blandt terapeuter, healere, akupunktører og sportspsykologer?

I forgangne tider kunne djævlens tilstedeværelse spores i det krogede og gevækstfyldte legeme, hvilket gjorde, at især ældre udstødte kvinder stod i fare for at blive jaget som hekse. Også i dag sidder djævelen i kødet. Det er fortsat alderdom og dødelighed, der spreder frygt, men syndens tegn kan findes $\mathrm{i}$ alle aldersgrupper. Synden sidder nemlig i fedtet. Ikke de mørke pletter på kroppen, men det hvide fedt er tegn på den truende uorden, på angreb mod sundhed og anstændighed. For mange mennesker er det ikke det gode, der kæmper mod det onde, men det sunde mod det usunde eller rettere det onde er blevet alt det, der truer drømmen om det sunde liv og den lydefri krop. I dette enkle verdensbillede dæmoniseres fedtet som indikator på, om man har handlet ret eller vrang som menneske. På TV gennemeksercerer idrætseksperter grupper af arme, tykke, syndsplagede nyligt omvendte mennesker med kameraets altid vågne øje hvilende på sig. Gud ser alt! Og seerne kan forstå, at fortabelsen kan afværges, hvis man er villig til at tage turen gennem skærsilden, hvor man kan lutre sig gennem afbrænding af det syndige fedt.

Af og til får kampen for den sunde krop også i dag halvreligiøse undertoner. Ernæringsguruen og fedteksorcisten Anne Larsen peger i lighed med en forgænger som Kaptajn Jespersen på sin personlige omvendelseshistorie for at trække sine tilhængere væk fra fortabelsen i fedtet og ind i en tilstand af »kærlighed « og »kosmisk fryd «. Og den holistiske livsstilslæge Søren Ventegodt opfordrer til, at vi skal lytte til vores »indre stemme« og leve i overensstemmelse med vores »autentiske livsprojekter« for at undgå sygdomme som kræft, som den moderne lægevidenskab fortsat langt fra har fået bugt med. Skønt det er vigtigt, at vi tager det psykosomatiske område alvorligt, bør det efter min mening ikke ske ved, at vi pålægger i forvejen hårdt ramte patienter skyldfølelse oven $\mathrm{i}$ deres organiske lidelse, oven i købet på basis af medicinsk spekulation.

Ikke mindst i en tid hvor lægevidenskaben er blevet stadig mere specialiseret, er det imidlertid vigtigt, at sundhedsagitationen kan fremføres af karismatiske inspiratorer, der via det personlige eksempel virker vækkende på søgende mennesker. Problemet opstår først, når sundhedsstrategierne forbindes med tabuer, følelser af skam og skyld og totalitære perfektionsdrømme. I kampen mod den galopperende »lipofobi« - fedthaderiet - gælder det om at udvikle en kærlighed til det fedt, der i moderate mængder og på de rigtige steder er nødvendigt for menneskekroppens opretholdelse. Fedtet omkring indvoldene støtter organerne, og også andre vitale kropsdele som f.eks. øjehulerne betjener sig af fedtets stabiliserende funktion. Fedt er én af kroppens byggesten og ikke blot degenereret væv. Du er din krop. Og du er ditfedt - på godt og ondt.

Meget tyder på, at slankekurene ofte slår menneskers appetitregulering i stykker og stik mod hensigten på længere sigt medfører vægtforøgelse. Fedtangst skaber fedtfascination, som anoreksi kan afføde bulimiens grovæderi. Men fedt i mådelige mængder kan virke appetitregulerende, fordi fedt har en fantastisk evne til at mæt- 
te, og umættede fedtsyrer har oveni købet sygdomsforebyggende virkninger.

Historikeren Jes Fabricius Møller har vist, at det i midten af forrige århundrede især var næsen og lugtesansen, der var central i de herskende klassers identifikation af og afsky ved de lavere klasser og udsondringerne fra deres kroppe og stanken i de fattiges lokalmiljø. ${ }^{20} \mathrm{I}$ dag er det snarere øjnene og synet, der er blevet den distancerende sans, der kan væmmes over den fede krop som tegn på manglende livsbemestring. Denne fedtets ulækkerhed blev for $\emptyset$ vrigt kosteligt visualiseret i filmen Fight Club, hvor de to hovedpersoner stjæler udsugningsfedt i hektolitermål fra en sk $\emptyset n$ hedskirurgisk klinik med henblik på at bruge glycerinen til nitroglycerin. Fedt er det rene dynamit!

Med et udblik til USA er der dog også et andet scenarium, der melder sig; muligheden for, at fedmeepidemien breder sig så langt ind i middelklassen, at den fede krop bliver norm, kort sagt at der opstår et folkekrav om, at fede ikke diskrimineres, men at tværtimod de offentlige rum, tøjstørrelserne, møblement, biografer, flystole og elevatorer indrettes på de store kroppe, samtidig med, at de fedmerelaterede sygdomme gives højeste prioritet. Herved vil forestillingen om normallegemet ændre sig, og BMI blive flyttet opad, men dog næppe under sloganet: »Survival of the Fattest! «.

Når fedmeepidemien tillades at gå grassat i USA skyldes det, at den militære overlegenhed i dag ikke længere menes i samme grad at være bundet til det veltrænede legeme med højt konditionstal, men til teknologier, der substituerer mandekroppens kampkraft. Måske en forhastet opfattelse.

Man kan også frygte, at selve fokuseringen på og diagnosticeringen af fedmen vil gøre det mere legitimt at udvikle en identitet som fed. Gennem de sidste år har vi set en meget stor stigning i sygdomme med et meget ringe påviseligt organisk grundlag såsom multiallergi, depression og fribromyalgi (kronisk lidelse med udbredte muskel- og senesmerter, rammer kvinder ml. 30 og 50 år), hvilket i form af langvarige sygemeldinger og førtidspensioner i meget høj grad belaster de offentlige udgifter. Det synes som om rollen som syg for nogle mennesker giver mening som svar på et net af sociale og psykologiske problemer. På samme måde så man omkring århundredskiftet, hvordan kunstnere, mest markant forfatteren Herman Bang, iscenesatte sig selv som »degenereret « med en aparte adfærd, men også med en øget følsomhed over for tidens puls. Og datidens kvinder kunne få sig en fortjent rekreation på kuranstalt, hvis de hoppede ind i kategorien som nervesvækkede.

Gennem de seneste år har det offentlige iværksat den ene kampagne efter den anden, der, som etnologen Signe Mellemgaard har vist, måske mere får til resultat at bekræfte de i forvejen frelste i deres valg af den rette livsmåde end at få fat i de fortabte syndere, der er dømt til at henslæbe deres liv langt fra sundhedsbudskabets stråleglans. Vi oplever i dag det paradoks, at mange af dem, der ikke har brug for at tabe sig, konstant er på slankekur, mens de, der vitterligt er for fede og utrænede, er helt uden for sundhedskampagnernes rækkevidde.

Sundhedskampagnernes manglende effekt hænger sammen med, at det har været anset for godt forældreskab ikke at knægte børnenes lyster og krav. Samtidig er de sidste årtiers ændring i de socialpsykologiske krav fra genital (sex) til oral kontrol (spise) tydeligvis ikke fuldbyrdet blandt den tungere del af befolkningen. Det er ikke længere kønsorganerne, der er tabuzonen, men bugen, der ikke bør vises frem i de offentlige rum. Og når det alligevel sker, er det 
fordi, den er forsvundet gennem mave$\emptyset$ velser og nedsat fødeoptag. Småpigernes og de yngre kvinders eksponering af bugregionen modsiger altså ikke denne tendens, for det handler jo netop om fokusering på det, som ikke er.

I den seneste tid er der endelig blevet taget vigtige spadestik til at imødegå den tiltagende svækkelse af menneskekroppen gennem påpegning af motionens betydning. De Forenede Nationer og WHO har annonceret et nyt verdensomspændende tiårsinitiativ kaldet »Bevægeapparatets årti «, og EU har udpeget 2004 til idrættens årti. Herhjemme er der blevet nedsat et »Forum for motion «, der har som formål at bekæmpe den fysiske inaktivitet. Det nyeste tiltag er, at en FNrapport udgivet af WHO og FAO ved siden af diverse kostråd anbefaler mindst en times daglig moderat motion.

\section{Lysten driver varket}

Hvis sundhedsstrategierne skal undgå tendenser til formynderi og sundhedsfanatisme, er det vigtigt at udvikle alternative strategier især ved at betone lysten frem for selvtvangen. Vi kan ikke vende tilbage til den gamle indrestyrede karakter, men må i stedet bruge sanseglæden i oplysningen. Vi må politisere lysten!

Allerede I.P. Müller havde forstået nødvendigheden af at bruge lysten $i$ fornuftens tjeneste, når han $\mathrm{i}$ sin lidt specielle stil skrev:

»For sundhedens skyld kan man ikke få alle de liderlige og dovne mandfolk til at ove gymnastik og friluftsidrat med dagligt bad. Men det hjolper måske, når man forteller dem, at det er den eneste måde, hvorpå kraft og udholdenhed kan erhverves og bevares $i$ de kønslige såvel som $i$ alle andre fysiske funktioner ${ }^{21}{ }^{21}$
Her får man så lyst til at spørge: Hvorfor er der aldrig som led i AIDS-bekæmpelsen blevet produceret en lækker pornofilm, hvor brugen af kondom bliver til symbol på alt det frække og forbudte? Hvorfor lærer vi ikke vores børn forskellen på virkelig kvalitetsslik og det junkslik, de spiser. Fedt i de rigtige mænger og på de rigtige steder af kroppen er erotisk, og hvilken mand ville ikke gerne spise chokolade med den franske skuespillerinde Juliette Binoche i den franske film Chokolat? Vi kan ikke undvære fedtet, men skal finde måder at omgås det på uden lipofobi; angst for fedtet. Man ville næsten $\emptyset$ nske, at man var skulptør, når man hører Per Kirkeby sige, at han elsker alt det, der sidder løst på kvindens skelet. Og han går videre med at sige: »kvinder skal æltes«. I daglig ubevidst tale er der jo ikke nogen tvivl om fedtets fascinationskraft jvf. udtryk som »det er fedt « eller omvendt »det er for tyndt«.

I stedet for at appellere til folks dårlige samvittighed, bør muligheden for at bevæge sig - med et udtryk fra ligestillingsområdet - mainstreames, kort sagt indbygges overalt i vores dagligdag. Motion skal ikke være noget, man »får«, men noget man gør. At bevæge sig skal være del af vores umiddelbare, vanemæssige tilgang til verden. Det kan f.eks. ske ved målretning af bevægelsesteknologi eksklusivt til de handicappede og ikke til brug for alle andre, motionspolitik på virksomhederne, kunstige vintersportsfaciliteter, badeanlæg i vores havne, cykelstier til skole, (gen)oprettelse af legefaciliteter i relation til natur og arkitektur, mere idræt i skole, fritidsordning og på ungdomsuddannelserne, herunder gymnasium og HF.

Heldigvis har vi også fra naturens hånd en bevægelyst og udsigt til belønning for fysisk aktivitet i form af velvære ikke mindst gennem de såkaldte endorfiner, na- 
turlige morfinlignende stoffer, som dannes i centralnervesystemet, et ufarligt trip! Men hvorfor tilbyder vi kødets spægelse i glædesløse maskinhaller, når en indretning af vores naturområder kunne byde på både bevægelse og sanseglæde? Hvorfor tvinge sig selv til at dyrke spinning i et lukket og indeklemt rum, når man kan tage på cykeltur i det fri? Men igen: Hvis nogen personlighedstyper trives bedst med en indpisker og en cykel, der ikke vælter, så er det bare fint.

Alt i alt må målet være, at mennesker begynder at dyrke rigtig meget lystbetonet motion med det flow, den aktivitet giver, og derigennem få mulighed for at spise meget og god mad med det flow, det giver.
Vi skal kort sagt ind $\mathrm{i}$ en positiv svingningsbevægelse mellem motion og mad, hvor lysten driven værket.

Problemet ved de traditionelle sundhedskampagner er, at der bliver mere mørkt uden for sundhedsoplysningens spotlys. Lysstrålen skaber en blindhed over alle menneskets latente, dunkle og forbudte lyster uden for fornuftens selvindlysende domæne. Det er ikke mindst her, at den humanistiske sundhedsforskning kan supplere den naturvidenskabelige i forsøget på at skabe en enhed af det apollinske og det dionysiske, det rationelle og det lystbetonede, et blik for både det der er inden for og uden for lyskeglen. Dagblik og natteøjne.

\section{Noter}

1. Jeg vil gerne takke litteraturvidenskabsmanden Henrik Stampe Lund for givtige kulturanalytiske indspark til denne tekst.

2. Mellemgaard S. (1998), p. 275.

3. Om degenerationsbegrebets udvikling se Pick D. (1998), pp. 37-67. Om degenerationsforestillinger indenfor litteraturen se Pache W. (2000).

4. Bonde H. (1991a), p. 28.

5. Koch L. (1996).

6. Lützen K. (1998), p. 69.

7. Clod-Hansen A. (1895), p. 180.

8. Nye R. A. (1984), p. $310 \mathrm{ff}$.

9. Nordau M. S. (1895), p. 54.

\section{Litteraturliste}

Andersen J. Vildmanden: Sandemose og analismen $i$ mellemkrigstidens litteratur (København, 1998).

Bonde H. Mandighed og sport (Odense, 1991a).

Bonde H. I.P. Muller, Danish Apostle of Health. The International Journal of The History of Sport 1991b (3), pp. 347-369.

Bonde H. Kapitän Jespersen - ein Erweckungsprediger der Lebensreform - Über Gymnastik und Religion. Stadion, Internationale Zeitschrift für Geschichte des Sports 1993, pp. 5-25.

10. Virilio P. (2001).

11. Indenrigs- og Sundhedsministeriet (Forum for Motion) (2002), p. 7ff.

12. Lasch C. (1996).

13. Det følgende er baseret på Bonde H. (1991b).

14. Bonde H. (1991a), op.cit., p.21.

15. Bonde H. (1991a), p. 97.

16. Bonde H. (1991a), p. 29f.

17. Det følgende er baseret på Bonde H. (1993).

18. Det følgende er baseret på Bonde H. (2001).

19. Jvf. Andersen J. (1998).

20. Møller J. F. (2003), p. 138ff.

21. Bonde H. (1991a).

Bonde H. Niels Bukh - En politisk-ideologisk biografi, bd. I \& II (København, 2001).

Clod-Hansen A. Mand og Kvinde (Købehavn, 1895).

Indenrigs- og Sundhedsministeriet (Forum for Motion). Børn og motion (København, 2002).

Koch L. Racehygiejne i Danmark (København, 1996).

Lasch C. Eliternes oprør - og forrcederiet mod demokratiet (Højbjerg, 1996).

Lützen K. Byen tcemmes (København, 1998). 
Mellemgaard S. Kroppens natur (København, 1998).

Møller J. F. Biologismer (Ph.d.-afhandling v. Københavns Universitet, 2003).

Pache W. Degeneration-Regeneration (Würzburg, 2000).

Pick D. Faces of degeneration (Cambridge, 1998).
Nordau M. S. Degeneration (New York, 1895).

Nye R. A. Crimes, Madness and Politics in Modern France - The Medical Concept of National Decline (New Jersey, 1984).

Virilio P. Hastighed og politik (København, 2001). 